\title{
Håkan Gunneriusson
}

Swedish Defense University (Sweden) \& Mid Sweden University (Sweden)

\section{Hybrid Warfare and Deniability as Understood by the Military}

\begin{abstract}
Russia and China are terraforming the maritime environment as part of their warfare. In both cases the actions are illegal and the performance is offensive to its actual nature. In the case of China, the practice is construction of artificial islands in the South Chinese Sea and in the case of Russia it is about the infamous bridge built over the Kerch strait, Ukraine. Neither Russia nor China expects an armed conflict with the West in the near future. That is a reasonable assumption, which is weaponized at the political-strategically level. The attack of this weaponized situation is that the trust in the West. Primarily the EU (European Union) and NATO (North Atlantic Treaty Organization), is eroded for every day which these countries challenges the international system which the western democracies say that they present and defend. China and Russia offer their authoritarian systems as a replacement and there are a lot of pseudo-democratic or even out-right authoritarian regimes on the sideline watching this challenge unfold. The article highlights the difference for the NATO-countries in logic of practice when it comes to the political social field on one hand and the military political field on the other hand. The article uses material from a previously unpublished survey made on NATO-officers then attending courses at NATO Defense College (NDC).
\end{abstract}

Keywords: South Chinese Sea; China; ASEAN; PMSC; Hybrid warfare; National security policies; NATO policy and doctrines; exploitation of cultural asymmetries; state vulnerabilities; reflexive control; NATO Defense College

Covenants, without the Sword, are but Words, and of no strength to secure a man at all (Hobbes, 1962). 


\section{Perspective on Hybrid Warfare}

The purpose of this article is to show that deniability is important for Russian contemporary warfare; this is exemplified with the Russian military actions in Ukraine, but also by its use of Private Military and Security Companies (PMSC) ${ }^{1}$. The article further discusses that the deniability primarily works on the political social field, while the military social field does have a more critical view of Russian military practice. The Russian logic of practice has inspired others, as China to undermine, the international systems as we know them ${ }^{2}$. The success of the deniability is limited to the political social field in what the article addresses as the West. It is limited as the military social field of the West (here represented by a survey on high ranking NATO-officers) does perceive the Russian and Chinese warfare by the logic on the military social field. This logic is more oriented to objectively assess military actions as such, and not consider the political consequences of this assessment as a priority (this is exemplified by survey results. The survey shows that there is a difference in the interpretation, if not perception, of Russian logic of practice on the Western political social field on one hand and the military social field on the other.

When researching military matters it is important to consider what the actual military who eventually will be the decision makers in crisis or conflict has to say. Sometimes the pursuit of academic writing can isolate one from the world outside with the risk of finding oneself in an ivory tower. This paper reflects on certain aspects of the contemporary discussion on hybrid threats and compares these arguments to the views of seasoned NATO officers $^{3}$. The term itself will inspire new perspectives with a heuristic explorative approach meaning it is defined by the empirical logic of practice. Still the term hybrid threats or hybrid warfare is a theoretical term, not an empirical one found in the empirical material. Which is important to remember as criticism of the term sometimes focuses on its absence in the empirical material, e.g. Russian doctrine. It is an academic fallacy to interpret this as important for a theoretical term (Giles, 2016). If one looks solely at Russian doctrine one might recognize the same overarching features of those from the USSR (The Union of Soviet Socialist Republics) era. It is not the Russian warfare in itself, which is novel. Rather it is in the Clausewitzian duel situation between the West and Russia where we find a novelty.

${ }^{1}$ Deniability is in this article the Russian ability to deny waging war on Ukraine, despite the West being sufficiently informed. With the West the article narrowly means the EU and NATO. But in a broader sense one could argue for a cultural definition, which is beyond the scope of this article though.

2 The article refers to the international systems in plurals as it really is a host of different systems and not a singularity.

3 The material about officers' opinions is taken from a Survey $(89,5 \%$ answer frequency), done by his paper's author, on Hybrid Warfare done on 38 (outcome) NATO officer's studying at NDC (NATO Defense College) Autumn 2018. They were Lieutenant Colonels, Colonels and a handful of Majors. They had a median age in military service at 28,5 years. See appendix for more on method. 
In the words of Marchel Duchamp, on art, it is in the meeting between the artist and the spectator that art is created. The keyword here is Russian deniability. As discussed in earlier articles, I interpret the logic of Russia's actions in Ukraine as criticism towards the West. (Gunneriusson \& Bachmann, 2017; Bachmann \& Gunneriusson, 2015). It is problematic to say that Russia's deniability lies purely in the opaque nature of Russian command and control (Seely, 2017). Opaqueness is the expected norm from Russia on all levels of command. There is something else to it. The political leadership in the West is unwilling to confront Russia in an outright manner with the fact that it is waging a war of aggression on Ukraine. No Western leader has gone that far, even if there have been concerns expressed about Russia's role in Eastern Ukraine. For example, could Europe put pressure on Russia by not supporting its economy, which is mainly dependent on the export of energy? Despite sanctions Europe is increasingly dependent on Russian gas (Shiryaevskaya \& Mazneva, 2018). A record volume of 58,8 billion cubic meters of natural gas has been transported from Russia to Europe by the Nordstream pipeline in 2018 (Nordstream, 2019). This will likely not change to less Russian gas export to Europe with the new pipeline Nordstream2 - which will double the capacity of the Russian Baltic pipelines - in tandem with Germany's reduction of domestic nuclear and coal generated power.

Today there is little to no interest in the West to politically go against the rationality of the progressive globalized economy. That means that actions which increase political tension are not wanted. For example, now allowing Russia into The Parliamentary Assembly of the Council of Europe (PACE) is a clear sign that Europe is not ready to call Russia out for its actions on its neighbor Ukraine, but rather fold (Oliphant, 2019). Status quo regarding international trade might very well be disturbed if forceful sanctions on the free-flowing supply of Russian gas in Europe, or against Chinese trade in general, would come in force ${ }^{4}$. If the worst would happen, and armed conflict involving NATO with Russia or China would really change the global economy to the worse, no matter the severity of the actual conflict itself. If there is no such willingness among the Western powers to risk economical values and the material welfare in our western countries, then the West's political consensus will be driven by market-based logic. This will be in conflict with an urge to uphold international law versus Russian or Chinese aggression.

However, there is a different attitude between the proxy wars of the Cold War and the Ukraine scenario. Back then there would have been a stronger effort on putting the actual blame on the USSR for any cross-border incursion. Today's political social field is governed by the rationality of a liberal globalized economy. It competes with the political rationality

${ }^{4}$ Donald Trump's presidency has been marked with some instances of hard rhetoric versus for example China, mostly not going much further than the rhetoric though. The criticism of this policy is on the other hand telling that the politicians of Europe and the US are not really on the same track come increasing tension, not to mention that media is mostly critical towards a hard stance versus the Chinese communist regime. 
that was dominant during the Cold War. The discursive ideological fight during the Cold War was very much alive, along the lines of a political social field ruled by ideological interests. The political rationality of today is mostly focused on having the international economic system working, which an ideologically driven conflict or even attitude might undermine. What we see now is that the success of Russian deniability is about us, not about Russia, willingly looking the other way. Not only because we do not want to risk an escalation, possibly ending in a worst-case scenario with an open war with Russia, but also out of a complacent attitude that comes from the material rewards which the globalized economical system brings. In addition to the West's complacency about geopolitical incursions with all but the least costly responses, the EU and NATO do not have the current military capability to challenge Russia in the Black Sea region, which is paramount to have if operations in Ukraine ever should come to reality. The willingness to go to war varies of course between countries. Without the initial decision from the US there would not have been engagements in Iraq and Afghanistan. None of these conflicts did practically extend the existential threat beyond the personal in the operational area. Engagement in Europe for EU and NATO versus Russia - with or without nuclear weapons is another scenario when it comes to existential threats ${ }^{5}$. This matters very much, as it is what shapes the Russian warfare against the EU and NATO in a new way (Snegovaya, 2015). As I have discussed in earlier articles I interpret the Russian logic of practice in Ukraine as a vehicle for raising criticism towards the West and the international systems (Gunneriusson \& Bachmann, 2017; Bachmann \& Gunneriusson, 2015a; Bachmann \& Gunneriusson, 2015b; Bachmann \& Gunneriusson, 2014; Gunneriusson \& Ottis, 2013).

The term hybrid can by that be seen as a phenomenological term. With that I mean that how the political society in the West reflect and thus also act on the warfare in Ukraine, is part of Russian reflexive control. That very reflexive control results in hybrid warfare against the West. (Gunneriusson \& Bachmann, 2017). Reflexive control in a military context is about acting in a way so that the enemy in its turn acts according to a plan favorable to the plan of the first part. We can see that there is a gap between what Russia actually does in Ukraine, regular warfare and our actual reaction to that practice of warfare in Ukraine $^{6}$. Our phenomenological representation of the actual warfare is not the one that Russia is performing a War of Aggression on Ukraine. No matter what we intellectually are able to perceive. If the case would be that we pointed out a Russian War of Aggression in Ukraine we would be forced to either stand up for the international convention against War of Aggression, or not. It could also involve engaging both the ICJ (International Court of Justice) versus Russia and try to get the ICC (International Court of Arbitration) to act

${ }^{5}$ For an in-depth analyses of the Russian military program, see (Cooper, 2018).

6 The Russians does not apply airpower in Ukraine, except at the initial phase of the conflict (Interfax-Ukraine, 2014), which actually is a show of restraint only explainable by the Russian willingness to allow us to look the other way - which we do (i.e. reflexive control). 
against individual actors in Ukraine and Russia ${ }^{7}$. One the other hand if we state that Russia actually is waging a War of Aggression in Ukraine and do not do anything about it, then we plainly admit that we do not stand up for international law. In that case we would standup against Russian aggression with a military intervention it would lead to an escalation which would not benefit the globalized economic logic of practice which rules the political social field of the West ${ }^{8}$. In the case that the West states that Russia is a perpetrator of a War of Aggression but do not carry it further, Russia would be proven right that the West is weak. The best option for the West, at least based on our current practice, is to not call Russia out. This is an example of Russian reflexive control on the West, a by Russia pre-calculated Western choice of action.

The events in Ukraine are not happening in a vacuum though, and one can argue that it has its inspiration not in Russian doctrine but in NATO practice. I have recently discussed the separation of Kosovo from Serbia as a blueprint for the Crimea annexation. This event bears certain similarities to the annexation of Crimea, at least from a Russian perspective. The intervention and further separation of Kosovo from Serbia was an ad hoc solution from the West. It was not meant as a precedent, certainly not for Russia who created a new pattern to use from this case. They reused that logic of practice on their neighbors like Georgia and Ukraine. The illusio, the unwritten rules of the social field of the international community - to speak with the words of the French sociologist Pierre Bourdieu - was at least changed with the parting of Kosovo from Serbia, if not before. It was then confirmed that something had changed with the following Russian annexation of Crimea. By then two major international actors on the field, NATO and Russia, each had used this logic of practice (Gunneriusson, 2017). Russia used the narrative from the case of Kosovo, even if not openly stating it, as a legitimating tool for the annexation of Crimea. It helped them in their effort to build the required minimum of legitimization for their annexation; at least they can hold an argument for it. This is a form of Lawfare (Bachmann \& Mosquera, 2016). Furthermore, Russia's massive military supremacy in its border region suggests that Russia's success was given. This is true as long as there is not really much to do, in military terms, about Russia's activities in Ukraine if one does not want to face possible dire scenarios. Realpolitik beats finesse in many cases, as in this example.

7 The Security Council would for obvious reasons not ask for the ICC to act against Russia but the ICC consensus Prosecutor could start an investigation of her own: proprio motu. That would then have to be approved by the judges of the ICC's Pre-Trial Chamber, which also might present a problem, even if it is a lesser problem than getting the consent of the Security Council.

8 The term is associated with the theories by the French sociologist Pierre Bourdieu. It can be described as: "a field is a system of relations between positions occupied by persons and institutions in a struggle for something with a common interest". There are plenty of references for the theoretical foundation, I merely list a few here: (Bourdieu, 1977; Bourdieu, 1984; Bourdieu, 1996; Broady, 1998). 
There are other types of non-kinetical challenges aimed at the EU, even at the steps of the unions border. For example, is Turkey's weaponization of migration another case of a state which challenges the political strength of the EU with possible aim to erode its strength. Turkey can be seen as one of the bystanders being inspired by Russian logic of practice come hybrid warfare. The Turkish regime has weaponized the Syrian conflict versus the European Union in no uncertain terms ${ }^{9}$. Or with Erdoğan's own words: "I am proud of what I said. We have defended the rights of Turkey and the refugees. And we told them [the Europeans]: 'Sorry, we will open the doors and say goodbye to the migrants' [...] We can open the doors to Greece and Bulgaria anytime and put the refugees on buses" ${ }^{\prime 1}$. In this context the European Union pays Turkey for retaining and taking back migrants for multibillion concessions monetary concessions and other political concessions as well ${ }^{11}$. The European Union frames it as a humanitarian program, which is also a non-confrontative approach; i.e. looking the other way. EU could on the other hand see it as less of a program for Turkey's part and more as handing Turkey the money which Turkey demands to keep the border towards the EU tight ${ }^{12}$. Erdoğan has been very outspoken about his view so it is not farfetched to actually take him on his words and see his migration politics for what he says it is.

\section{Complementary Takes on Hybrid Warfare}

There has been some other research on hybrid warfare which is not touched upon above, but relates to the perspective described above. It is therefore important to touch upon these perspectives. There is also a purpose of itself, albeit secondary, to discuss the different takes of hybrid warfare which constitutes a plethora of different takes on the term. It will thus be useful to comment upon and also to relate to the perspective presented. This made in order to give a foundation to further the content of the survey. Hybrid Warfare has been described as a "catch-all", by Robert Seely, for anything occurring in the interface between the military and non-military effects used against the West. He also argues, as some others do, that there is nothing new in the Russian way of war (Seely, 2017). There is a plethora of different uses

9 Rather similar to when Italy paid Muammar Gaddafi $\$ 500$ million worth back in 2008. This was the cost of the dictator to keep down the level of refugees transiting through Libya, even if Gaddafi used an argument for payback because of Italian colonial past as legitimating argument. The Italian prime minister was more direct in RAI, the Italian state television: there should be "fewer clandestine migrants leaving Libyan shores for Italian" coastlines. https://www.nytimes.com/2008/08/31/world/europe/31iht-italy.4.15774385.html.

10 https://www.theguardian.com/world/2016/feb/12/turkish-president-threatens-to-send-millions-of-syrian-refugees-to-eu.

11 https://www.dw.com/en/eu-turkey-migrant-deal-done/a-19127595.

12 http://europa.eu/rapid/press-release_IP-19-1_en.htm.

https://www.yenisafak.com/en/news/turkeys-vice-president-meets-eu-humanitarian-official-3471112. 
of the term Hybrid Warfare that much is clear. It is natural as there is no central thinker or school of thought behind it, the term is very much an object for discourse. This article does not deal with the question if the warfare described can be called new or old forms of warfare. The use of that kind of arguing is very limited in a practical sense. The focus is instead on categorizing consequences for NATO of the Russian warfare in Ukraine, no matter if it can be called old, new or something else. That is another reason for the term hybrid being so diverse. People, researcher, politicians and journalists primarily, apply it on all levels of warfare ${ }^{13}$. This text focuses on hybrid warfare as a changing perception of the West among countries but also as a communication directly to the populations of all states which might be reached with this communication. I fully agree that there might not be anything new in the Russian way of war or at least nothing going in a new direction when just looking at Russia. Not at least if one aims to find something new in the nature of the war, which by Carl von Clausewitz deals with the constants of war. It would be the scientific equivalent to find a new element in the hypothetical Periodical System of War. But as every conflict is unique in its details one might in each case find some things which is characteristic for a conflict. Clausewitz did after all also bring up the character of war, the specific empirical oddities which a conflict might present. I am convinced that the ambition to find anything new in war should be on the level of character and not nature of war - if not for anything else, in order to not be all too disappointed.

The researcher Ofer Fridman presents the Russian take on the term hybrid warfare, called Gibridnaya Voyna. Their view on the term is closer to the one which is explained in this article, compared with the Hoffman view that it is about a mix of regular and irregular warfare. Francis Hoffmann's staging point is that hybrid is basically a hybrid between regular and irregular warfare. "Hybrid Wars incorporate a range of different modes of warfare, including conventional capabilities, irregular tactics and formations, terrorist acts including indiscriminate violence and coercion, and criminal disorder" (Hoffman, 2007). More specifically hybrid warfare is performed by an irregular actor (Hezbollah in Hoffman's case) possessing capabilities which mainly a state actor is assumed to possess (Gunneriusson, 2012). The article by Fridman has also an interesting historical background for the Russian use of the term (Fridman, 2017). Subversion is paramount in the Russian interpretation of the hybrid warfare. According to the Russians, gibridnaya voyna is about attempts to erode the socio-cultural cohesion of the adversary's population, ultimately leading to the replacement of an unfriendly regime by a colour revolution, with minimum (if any) military intervention (Korybko, 2015). The Russian's see the West as perpetrators when it comes to hybrid warfare, the example of Kosovo above is one instance which Russia could point at. It might be natural that they so do, if not for other reasons because it is a natural part of the Russian information war to state just that it is the West and not they who are

${ }^{13}$ For parallels with how the development of the military theoretical term Effect Based Operations went, see (Gunneriusson, 2017). 
the perpetrators. This article on the other hand explores Russia as the perpetrator, set on a discursive path to undermine the trustworthiness and apparent political and military resolve of West. That is rather similar to what the Russian's themselves see as hybrid warfare. Hybrid warfare has been described as an example of Ontological Insecurity "a condition underpinning the actor's ability to act in the world with basic confidence about how the world works and her own place within it" (Mälksoo, 2018). In the case of hybrid warfare narrowed down to a "deep, incapacitating state of not knowing which dangers to confront and which to ignore, i.e. how to get by in the world"14. I sympathize with that idea as an intellectual concept. The perspective pursued in this article argues on the other hand that the West do actually know which dangers to ignore. But the West just won't admit it as the logic of practice in confronting Russia in Ukraine is not very appealing.

One can conclude that Russia gets away with little punishment when it comes to its aggressive actions towards and in Ukraine. As there is no economic rationality to act with force against Russia, it is likely that Russia not be deterred. This on the other hand will further erode the trust in EU, NATO and the international systems. Russia is in this showing itself strong and able to inspire other actors too, as all of this is in plain sight. In the following we turn to look at the Western military view on Russian action, but also at the view on Chinese actions in South Chinese Sea; which bears certain similarities to Russian practice as described above.

\section{NATO's Description of Hybrid Warfare ${ }^{15}$}

NATO's description [sic] of Hybrid Warfare is rather close to the one described above. It should be given a brief description here, in order to give material for further incorporation in the survey. Hybrid Warfare is not new, what is new is that it has moved from the operational to the strategic level, underpinned by new dimensions such as: globalization; complex geostrategic environment; advanced technologies (cyber); and information demand.

${ }_{14}$ The quote is from (Mitzen, 2006, p. 345), but quoted in relation to hybrid warfare in (Mälksoo, 2018).

15 The following is taken from LtCol Hans Andersen's presentation at symposium Hybrid Threats and Asymmetric Warfare: What to do? At the Swedish Defence University 14-15 November, 2017, Stockholm, Sweden, the proceedings later presented in "Hybrid Threats and Asymmetric Warfare: What to do?", Stockholm, Swedish Defence University, 2018. He was then Staff Officer for Strategic Plans \& Policy, NATO, Allied Command Transformation Virgina from 2014, the one tasked with writing on Hybrid Warfare at Allied Command Transformation (ACT), Norfolk for his whole stint there. He is in other words a primary source for NATO's take on hybrid warfare. Beside that occasion the author has worked with him on Hybrid Warfare at the Exploratory Team MSG-ET-043 meeting on Hybrid Warfare Modelling and Simulation in Rome 2016 and The Workshop for the Strategic Military Partners Conference (SMPC) in Izmir 2016. The NATO description and the one favoured by the author of this article does not diverge much even if the emphasize differs. Andersen is very clear on that it is not a definition, much due to the integral uncertainty of what the attacks could constitute of. 
Russia is always inside the western OODA-loop (observe, orient, decide, and act-loop) by being swift in its decision making. NATO needs an agreement between its member states to mitigate the organization's long decision processes that take time. Characteristics of Hybrid Warfare according to NATO includes that it is part of an overall strategic plan which is highly integrated and synchronized.

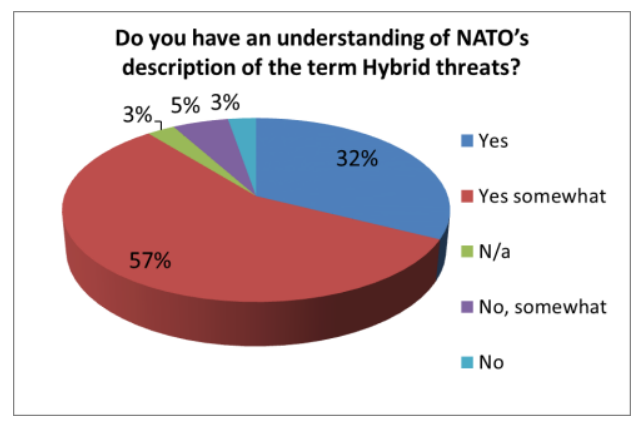

$89 \%$ of responding NATO-officers in the survey did selfevaluate themselves as understanding NATO's description of hybrid warfare.

The Hybrid part of the strategic plan can be characterized as a combination of the conventional and unconventional means employed. Among those can be mentioned overt and covert activities, military, paramilitary, irregular, state and non-state and civilian actors directed at an adversary's vulnerabilities. This is complicating decision making across the full DIMEFIL-spectrum where ambiguity and denial is central for the perpetrator's plan. Globalization and technological advances has led to increased vulnerabilities ${ }^{16}$. One can expect increasingly sophisticated cyber-attacks as well as far reaching complex propaganda and disinformation campaigns. This combined with targeted and coordinated political and economic pressure. The 3 pillars of NATO response versus hybrid threats are Prepare, Deter and Defend. The EU is important for NATO as dealing with hybrid threats needs to be part of a collective effort. Deterrence against hybrid threats requires a focus on the population's and elite's mind-set and the harnessing of a new defensive spirit. NATO needs swifter coordination mechanisms to take control of the OODA-loop. Effective collaboration between EU and NATO is essential in efforts to counter hybrid threats.

16 This weakness of a globalized world is deeper than one can assume at first. It can be fitting to remind that this paper argues that the economic rationality of the globalized world has taken over as the rationality on the political social field the term discussed as Pierre Bourdieu uses it (see references). That means that political action which counters economic rationality is difficult to perform. An example of that is acting against Russia in Ukraine for political reasons based on ideological rationality which counters the global economy. 


\section{NATO-Officers on Hybrid Warfare}

From a western military standpoint, the significance of Russian activity in Ukraine is very clear, at least if the survey with a host NATO-officers from different countries participated ${ }^{17}$. That is because the military has no reason to look the other way when choosing an explanatory narrative of Russian behavior, as opposed to western political actors responsible for strategy. According to the survey conducted for this article, NATO officers find the hybrid scenario most relevant on the strategic-political level and ever less important down the command structure.

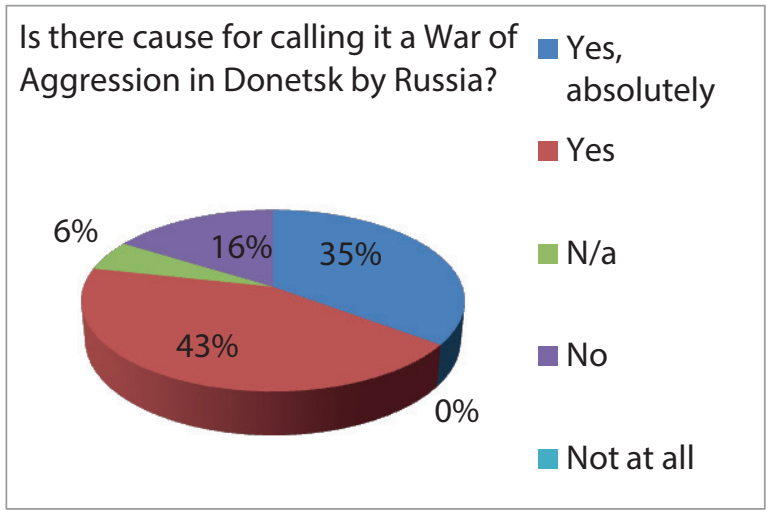

In this way we see that the hybrid element of Russian information warfare is a result of warfare in Ukraine in general, rather than inherently a type of combat waged only in Ukraine. However, actual Russian warfare in Ukraine has certain peculiarities on the tactical level. For example, is artillery used extensively in/into Ukraine by Russia/Rebels as compensation for the lack of air power (Rettman, 2015).

In order to enable Russian deniability and the hybrid aspect of their warfare on the political-strategical level, there are certain characteristics of the warfare in Ukraine rather than tactical level activity being hybrid itself. Here I am mainly referring to the lack of projected airpower. Since the initial outbreak of fighting, there has been no projection of Russian air power, or Ukrainian for that matter (Interfax-Ukraine, 2014). It is not an issue of Ukrainian anti-air or other air denial systems, as Russia is capable of delivering kinetic payload from the deep interior of Russia and to the middle Ukraine. Rather the absence of Russian airpower is for deniability. Russia has a proxy army in Ukraine, which is what enables the hybrid scenario ${ }^{18}$. The use of artillery systems such as MLRS (Multiple Launch

17 There were 32 participants from Europe and 6 from North America. The ranks among these were equivalent to: 5 majors; 16 Lieutenant Colonels; 16 Colonels and one undisclosed.

18 On proxy war and Ukraine, see Veljovski, 2017. 
Rocket System) seems on the other hand to be within the limits of what Russia can stomach to deny, even when fired from within Russia into Ukraine ${ }^{19}$. This is in itself interesting as it shows that the long-term strategic plan actually impacts the common soldier in Eastern Ukraine, removing airpower from the mix of conflict activities. The political-strategical hybrid approach does have a real effect down the whole chain of command. This is an oddity in modern warfighting which in all other respects, considering the use of artillery and armored vehicles, reminds us of conventional warfare. Russian ambiguity and denial of action can of course have short-term effects when it comes to reactions from NATO and the EU (Wirt, 2017).

However, the possible intended effect of exposing the West as passive might be an even more important characteristic of this conflict. There are many authoritarian or pseudodemocratic countries on the sidelines watching. Russia is showing restraint on the tactical level in Ukraine by not deploying air force, in exchange for deniability on the strategic level, which in turn is aimed at eroding trust in not only NATO but also the EU and the values these organizations stand for.

If these challenges against the West continues for a prolonged period, we might see a world emerge that is more governed by the logic of realpolitik in international Relations. If China and Russia continue unopposed in their geopolitical pursuits, it is just a matter of time. China is one of the absolute biggest economic players in the global market considering its dominant role as a manufacturer and exporter of goods. For China's part it all comes together in a consolidated political, economic and military strategy. China is apparently playing along the Russian tune when it comes to ignoring the international community and it is one of the actors watching on the sidelines to see what Russia gets away with. This is apparent with China's offensive practices in the South Chinese Sea where it constantly disregards legal boundaries.

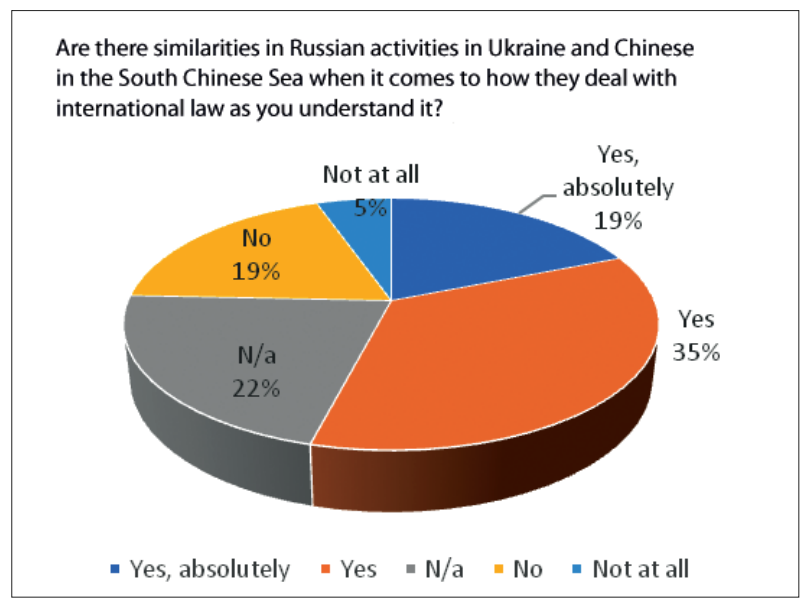

19 See for example the presentation of Bellingcat: Eliot Higgins. 
The survey on the senior NATO officers gave a mixed picture when it comes to the treatment of International law for Russia in Ukraine on one hand and China in the South China Sea on the other hand. The majority did in fact sees similarities. The responses illustrated in these results were given before November 2018, when Russia expanded warfare activities in the Sea of Azov. One can assume that responses would have underscored even more similarities after this escalation, as the maritime element of Russian actions increased by this ${ }^{20}$.

In 2016 the Permanent Court of Arbitration (PCA) rejected China's claims in the South Chinese Sea according to their interpretation of UNCLOS (United Nations Convention on the Law of the Sea) ${ }^{21}$. The case was brought to the court by the Philippines who are now not acting against China. With the change of leadership in the Philippines the Duterte administration has relaxed the country's stance towards China's activities at sea (Kyodo, 2018). If Duterte had been in power when the Philippines raised the issue, the situation might have more resembled developments in Ukraine and the Black Sea as the Philippines would likely not have brought the case up at all. China is no longer denying its actions in the South Chinese Sea, which differs from Russia's activities in Eastern Ukraine. Still, both scenarios involve denying the importance of international law and both have sought to lay territorial claims through terraforming activities, islands in the case of China and the bridge through the Kerch Strait in the case of Russia. The bridge construction has been weaponized for Russia to attack and seize Ukrainian boats around the structure (Greenfield, 2018). This is just another element added to Russia’s warfare against Ukraine. Russia is in violation of UNCLOS in this case, as China is with the reefs in the South Chinese Sea. One might argue that Russia is in an international armed conflict (IAC) with Ukraine, and then most of the Russian actions would in fact be lawful in bello ${ }^{22}$. No such recognition of the conflict is still to be made by any of the two countries or for example the UN as it predictably serves no one's purpose to make such recognition.

In both the cases of Russia and China the perpetrators are eroding trust in the international system and demonstrating that power rather than rules and norms is what drives international politics. After all, in both cases the smaller state succumbed to pressure from larger and more powerful state. This is also demonstrated by the fact that Ukraine does not clearly proclaim that Russia is waging a War of Aggression in the Ukrainian

${ }^{20}$ In the Sea of Azov, close to the Kerch Strait, Russia closed an area of the sea for navigation due to military exercises on 18-20 February 2019 with live fire (Unian, 2019).

${ }^{21}$ Spratly islands are often mentioned with at least 7 Chinese artificial islands, but Chinese expansion concerns many other areas, as Scarborough Shoal which was the area which the Philippines took China to court for. Macclesfield Bank, Pratas Islands, Senkaku/Diaoyu Islands and Paracel Islands are other areas which China claims in the South Chinese Sea. The most recent reef to be under Chinese construction, in November 2018, is the Bombay reef (Tang, 2018).

${ }^{22}$ The Russian treatment of the captured Ukrainian sailors is anyway not according to proper treatment, see Kraska, 2018. 
districts Luhansk and Donbass. An open existential war against Russia is not in any way on Ukraine's agenda any time soon. The Philippines is no longer going after China despite the ICA ruling it its favor. This could be a prelude for interactions between China and ASEAN countries in the future. There is an unsettling strand of logic in this, at least for those who believe in the international systems versus the strong realist approach of China and Russia. Russia and China are able to behave this way now because no one is really upholding and enforcing the international systems at present ${ }^{23}$. Given Russia and China's increasingly aggressive behavior, other state actors might perceive the situation as insecure or even military volatile.

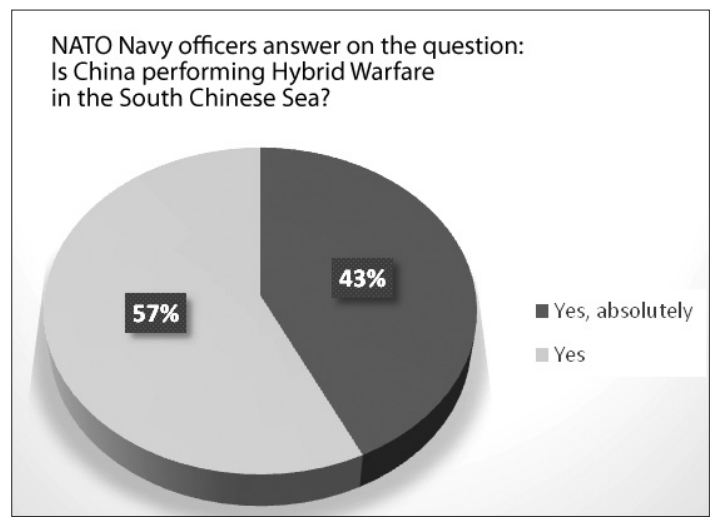

From the survey the verdict is very clear when asking NATO naval officers in the survey about the strictly naval matter of the Chinese behavior in the South Chinese Sea, being a case of hybrid warfare or not ${ }^{24}$. Take note that there is none answering any of the two "no" answers ("no" and "absolutely not") or even being unsure. The exact motive for the outcome of the answer was not asked in the survey. All but one thought that they had a good understanding of NATO's description of hybrid warfare so it is safe to assume that they responded from that point of view. The response on the political field is still rather lukewarm in its reaction on China's venture in the South Chinese Sea.

\section{Deniability, Private Contractors and the Military Perception of It}

The aforementioned use of a Russian Proxy Army is important as it gives Russia the possibility to be both somewhere and nowhere at the same time. This works as long as the West allows Russia to act this way, which Russia counts on. The trend with states using Private

${ }^{23}$ Another researcher who identifies the Chinese rationality as one close to the Russian is Wirtz, 2017.

24 The ranks among these were: 1 Lieutenant commander; 4 Commanders; 2 Captains (navy); all Europeans. 
Military and Security Companies (PMSC) is another aspect of deniability; examples of this are notably Blackwater/Academia for the USA and the Wagner Group for Russia). The term GONGO (Government Nongovernment Organizations) has recently surfaced as an indicating the prominence of this trend (Estonian Security Police, 2014). These troops do bring a certain degree of deniability for state actors (Spearin, 2018). The use of Russian PMSCs in Syria for example is well known ${ }^{25}$. It is likely that there will be an increased use of PMSC in the near future. The survey results further reinforce the importance of PMSC at it relates to the subject of hybrid warfare.

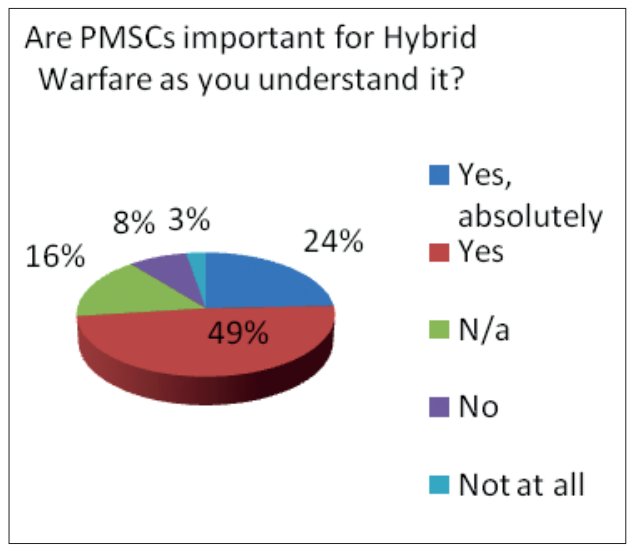

Russian President Vladimir Putin himself has been very clear on the utility of Russian PMSCs; they "are a way of implementing national interests without the direct involvement of the state"26. It has to be stressed that any unit can be made to look as a PMSC with a minimum of effort. The deniability of the Russian PMSCs is a legal issue but is more importantly an issue with the deniability they provide for Russia. The West is unwilling to take an action in force against Russia due to risk of escalation. Russia offers the West the opportunity to not escalate politically in a situation where Russia is acting, with the Russian use of PMSC. There is enough empirical material to expose Russia and act if there is a willingness to do so. This feeds the Russian PMSC directly into the narrative of offering deniability.

NATO could - at least in theory - just state any time that they view these contractors as Russian troops, on Russia's payroll, thus calling a spade a spade. The utility of such an

25 These are only a small portion of the actual Russian military personnel that has circulated through Syria. An estimate is that 480000 Russians soldiers in total have been deployed to Syria at some point. It is also seen as an essential career move for Russian officer's to have Syria in their CV, e.g. the current Commander of the Western Military district general Kartapolov (Barrie \& Gethin, 2018).

26 Vladimir Putin cited in Sputnik International, "Russia May Consider Establishing Private Military Companies", 13 April 2012; quoted in (Spearin, 2018, p. 68). The topic of Spearin's article quoted in this article is mostly about interesting legal issues with PMSC 
attitude is of course limited as it could have suboptimal consequences. For example, the US could be forced to say that Russian and US troops have been in an engagement in which the US deliberately killed over a hundred Russian troops in Syria (Borger \& Bennetts, 2018; Yaffa, 2018). There is no interest whatsoever from either the US or Russia to acknowledge such an event as a state vs state action, no matter how clearly it has happened. The problem, and utility, with Russian PMSC, is more about our chosen perception of them and not about the legal status of the same PMSC. If we chose to see them as non-Russian, then we avoid a direct confrontation with Russia, which is good. But it also gives Russia a free pass to act while not taking responsibility for its actions. To maintain the veil of deniability the Russian usage of PMSCs will leave them with little possibility of indirect or direct support. One cannot both state that troops are not under national command and still provide them with indirect support, which undoubtedly is under national command. The lack of air power in Ukraine, a consequence of continued deniability, as in Syria with the Wagner troops follows the same pattern. In an episode 2018 - when Wagner troops faced the US's howitzers, jets and attack helicopters - in North Eastern Syria, there was no help available for the Wagner troops. Not because Russia lacked the resources - in fact Russia had ample air power in the region and Kalibr cruise missiles had previously been used in Syria - but because of the desire to maintain deniability ${ }^{27}$. This deniability may come at a high cost, but it does give Russia an expanded freedom to operate with its own troops in sensitive operations. Russia always has the opportunity to claim that their troops are not really Russians as long as they use PMSCs and as long as the West does not call Russia out on it. It is worth mentioning that there are other incidents where Russian and US troops have exchanged fire with each other in Syria ${ }^{28}$.

The survey results suggest that SF (Special Forces) have an important part to play in hybrid warfare scenarios. No question, the responses about the importance in a hybrid warfare scenario are most likely affected by the way Russia annexed Crimea $2014^{29}$.

${ }^{27}$ For example did the frigate Admiral Essen and submarine Krasnodar did fire four "Kalibr" missiles against targets based to the east of Palmyra, according to the Russian Ministry of Defence. https://www. telegraph.co.uk/news/2017/05/31/russian-warships-fire-cruise-missiles-isil-targets-near-palmyra/ https:// www.bbc.com/news/world-middle-east-40104728.

${ }^{28}$ According to US Ambassador James F. Jeffrey, who serves as the Special Representative for Syria, there have been at least a dozen of occasions where they have clashed. S. Atlamazoglou, "More than a dozen face-offs between US commandos and Russian forces in Syria, reveals US Ambassador", Newsrep, November 27, 2018, https://thenewsrep.com/110756/more-than-a-dozen-face-offs-between-us-commandos-and-russian-forces-in-syria-reveals-us-ambassador/.

${ }^{29}$ Russia has also developed their SF capability for some years now, the SSO, sily spetsialnykh operatsii. C. Marsh, 2017. 

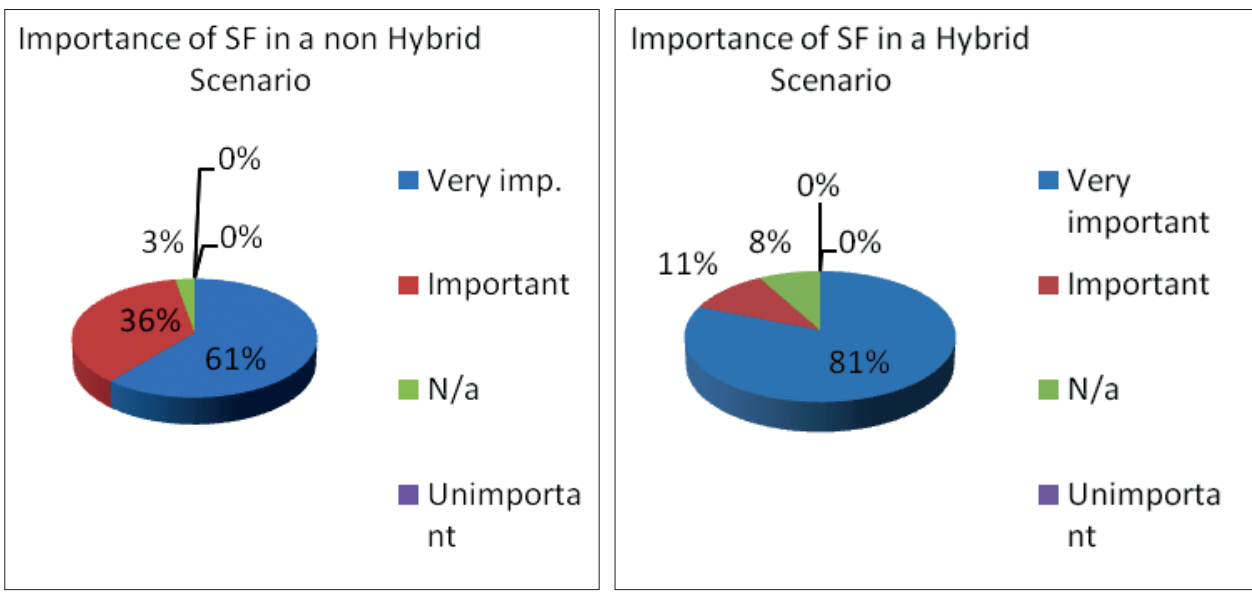

It might not be very surprising that senior NATO officers consider SF important in a hybrid warfare scenario. The hybrid intrusion on Crimea was highly dependent on SF which acted as PMSCs, even though the actual account paying their salary is unknown. The difference for SF in a hybrid warfare scenario is perhaps more noteworthy compared to all the other types of units taken in the survey. In a hybrid scenario the SF were very much in favor versus the other types of units combined, this with a factor of 2,6:1.SF in non-hybrid warfare was only meagerly $3 \%$ more important than the other unit types combined, not that much more important than other conventional tools of warfare that is. The results point to a future where deniability will be ever more important. As such the use of PMSCs and SF will probably continue to grow. This trend points toward a bleak future, warfare void of accountability. There might be a future with state actors navigating on the fringes of the international systems. NATO military officers seem to be aware of this evolving situation, at least given their responses to the survey. The military social field has no room for looking the other way; the military trade must deal with reality as true as it can. The problem is at the political level where the will to oppose China and Russias hybrid practices is weak. This is so because we in the West do not want to disturb the global economic system by going against states that violate international law, we stand to pay a price of decreased trust in NATO and the EU. That is more than a collateral effect; it is the hybrid damage of Russia and China's actions.

\section{Summary}

As the article shows there are a profound unwillingness for the West to act on Russian aggression and call Russia out. Neither are West stating that there is a war of aggression performed upon Ukraine by Russia, nor does Europe stop importing gas from Russia which the Russian mono-economy is clearly dependent on to continue. Russia is clearly playing 
this hand, as can be seen in showing tactical restraint in Ukraine. China is following suit by defying international law in plain sight in the South Chinese Sea and by that further undermining the West who stands for the values instituted in the international systems. Further the article shows a rift in the West on the military social field on one hand and the political social field on the other hand when it comes to the interpretation of Russian and Chinese actions. This is because the logic of practice on those social fields differs. The politicians do not want to disturb the global economic system, which a confrontation inevitable would lead to. The military on the other hand have no reason to look the other way and have a rationality which demands objectivity as the trade of war cannot be based on half-truths. With this trend continuing, we might observe a burgeoning challenge to the Westphalian system expanding. "The future is already here, it is just not very evenly distributed" as the science fiction author William Gibson once put it (Gibson, 1999).

\section{Appendix: On Method for the Survey}

The background above established the important causes for Russian Hybrid Warfare as producing political strategical attitudes according to Russian reflexive control. The survey establishes among other things if attitudes within the NATO military sector is an important cause for these attitudes. An important cause should produce some kind of regularity in answers coming from the cohort answering a survey. This can then be applied to a systematic comparison of different cases. The case study at NDC can thus be seen as a pilot study, perhaps being used for further comparison later on. One might object that these kinds of casual surveys represent too much of internal diversity to be useful. It might on the other hand be some systematic flaw, as for example regarding the choice of people answering the questions, or how they are lumped together. That might be true, but the problem is known and has been considered during the construction of the survey and when it was given to the responders. If the surveys really do not make anything stand out then it might be so that it is a perfectly valid outcome. One might also object that the regularity does not state that it is an important regularity. In this case I would say that the previous research suggesting that the subject of the survey is important is enough to validate the importance of the possible regularity's importance to explain the severity of Russian hybrid warfare on NATO.

The questions were sorted into two different levels of belts. The first belt of questions was based on a model for Warfighting capacity used by, at least, the UK and Sweden in their doctrines. The UK uses a model with three circles which in the overlapping area for the three circles represent Warfighting Capacity. Sweden uses a model of an ancient temple with the three areas (see below) representing the three pillars holding up the temple of Warfighting Capacity (British Army, 2017) \& (Försvarsmakten, 2012) ${ }^{30}$. It is just a question of different

${ }^{30}$ From the Swedish doctrine a range of questions in the Survey is derived, regarding more concert representations of the conceptual factors. 
pedagogical takes on the same theoretical principle of defining warfighting capability. The three principles in the both models are Conceptual Factors (Doctrine, Policies), Morale Factors (Will, Leadership, Ethics) and Physical Factors (e.g. Units, Personnel). They together are what warfighting Capacity is built on in these theoretical models ${ }^{31}$. One can ask if these three factors really correspond to what has been reckoned as important for Hybrid Warfare as discussed above. Physical factors seem to be of less importance in the Ukrainian context compared with Morale factors and Conceptual factors, to mention the one thing which stands out ${ }^{32}$. This might very well be so; the survey tests the theoretical assumption on the officers taking the survey. What they thought on this matter was an empirical question. The higher belt of questions is answered by the sub-belt of questions sorted under each of the three principles mentioned above. This sub-belt of questions is based on what have been discussed in this paper. The process of sorting the questions under the tree different principles has been easy in many cases (e.g. questions on material and weapon systems are naturally sorted under physical factors). In some cases, it has been delicate to classify the questions; i.e. some questions could depending on perspective be sorted under Morale, where leadership is sorted or under Conceptual factors which includes doctrines. The final home - which category of Warfighting category they belong to - of these questions are not a question of right or wrong, but more how the questions should be interpreted, depending on if it is classified as a Morale or Conceptual question.

The number of questions is based on empirical realities. In some cases, a question is more of a stand-alone, and in some there are a battery of similar questions accompanied by a similar other battery of questions. So that in order to falsify one question at the highest belt, then at least half of the sub questions should be invalid, there is a reliability argument built into this. Each of the questions at the higher belt aims towards giving an answer to an overarching question. This gives validity to the conclusions drawn from the survey. One cannot exclude the possibility that questions do not really point in the right direction: external validity or other similar problem. If we assume that one question, on any of the belts, do not fit the survey, as it falls out, there was still have a solid foundation for the actual survey with a battery of reduced amount of questions. The survey had a rather solid ground to stand on, as one need to falsify at least half of the remaining questions to fault the survey itself. The questions themselves are not chosen because of the importance of them. Some of them might seem less important than others at first hand, even if they fit under one of

31 These 3 factors are not formulated as questions but the sub-belt for each of them indicates the value of these three factors.

32 Hofmann's take on Hybrid matches very well with Physical capabilities s weapon systems not commonly associated with irregular troops are a stand out feature for him. In the case of Hezbollah they possessed rocket artillery, antitank missiles and even ASMs which the INS Hanit incident, 2006, suggests. There is a possibility that people answering the survey think along the lines that hybrid warfare about systems rather than conceptual or morale factors. 
the main belts of questions. The actual answers decide the importance of the questions, so that cannot be decided beforehand. Some anomaly might appear even at questions which beforehand seem to have a likely outcome, giving an unexpected indication. The questions in the three areas which define warfighting capacity are not weighted in importance towards the other categories. For example, might the responders answer that a high percentage of the questions in one category is not relevant for Hybrid Warfare. That does not necessarily mean that one can conclude that the category is unimportant. It might just be so that many of the questions are not really relevant but some others might be very important. One needs to do a qualitative analysis when it comes to this part of the study and in this article there have been no need to go further into that kind of analysis of the raw material.

All those who took the survey was informed that no attempt to track individuals behind the answer was to be made, even if cross-referencing data could allow for such activity. The questions do not pinpoint the nationality of the responder, but mere a general region. Data will not be complied in a way which would single out an individual as recognizable. All the answers from one group (e.g. one course) will be gathered together so answers from different sub groups (e.g. committees, which the courses are organized in) will not be possible to track. They were also informed that the researcher will keep the answers for himself and not store them by anyone else. Ethical considerations have been taken. The non-response on the survey at the Senior Course 133 and the Modular Short Course 133-3 among NATO officers was just $10,5 \%$ which is statistically acceptable.

\section{References}

Agence France-Presse. (2016 February 12) "Turkish president threatens to send millions of Syrian refugees to EU". Retrieved from: https://www.theguardian.com/world/2016/feb/12/turkish-president-threatensto-send-millions-of-syrian-refugees-to-eu.

Andersen, H. (2018). “Hybrid Threats \& Asymmetric Warfare: What to do?", Stockholm: Swedish Defence University.

Atlamazoglou, S. (2018 November 27). "More than a dozen face-offs between US commandos \& Russian forces in Syria, reveals US Ambassador", Newsrep. Retrieved from: https://thenewsrep.com/110756/ more-than-a-dozen-face-offs-between-us-comm\&os-\&-russian-forces-in-syria-reveals-us-ambassador/.

Bachmann, S. \& Gunneriusson, H. (2015a). "Hybrid Wars: $21^{\text {st }}$ Century's New Threats to Global Peace \& Society", Scientia Militaria - South African Journal of Military Studies, pp. 198-211.

Bachmann, S. \& Gunneriusson, H. (2015b). "Russia's Hybrid Warfare in the East: Using the Information Sphere as Integral to Hybrid Warfare", Georgetown Journal of International Affairs - International Engagement on Cyber, V: Securing Critical Infrastructure, 2015, pp. 198-211.

Bachmann, S. \& Gunneriusson, H. (2014). “Terrorism \& cyber-attacks as hybrid threats: defining a comprehensive approach for countering $21^{\text {st }}$ Century Threats to Global Peace \& Security", Journal for Terrorism \& Security Analysis. 
Bachmann, S. \& Mosquera, A (2016) "Lawfare and Hybrid Warfare-How Russia is Using the Law as a Weapon", Amicus Curiae - Journal of the Society for Advanced Legal Studies, p. 1.

Barrie, D. \& Gethin, H. (2018). "Russian Weapons in the Syrian Conflict", Russian studies, 01/18, Rome: NATO Defense College. p. 10.

BBC, (2017 May 31). "Russia fires cruise missiles at IS targets in Syria”. BBC. Retrieved from: https://www. bbc.com/news/world-middle-east-40104728.

Borger, J. \& Bennetts, M. (2018 February 13). "Scores of Russian Mercenaries Reportedly Killed by US Airstrikes in Syria", The Guardian.

Bourdieu, P. (1977). Outline of a theory of practice, Cambridge: Cambridge University Press.

Bourdieu, P. (1984). Distinction. A social critique of the judgement of taste, Harvard: Harvard University Press.

Bourdieu, P. (1996). The Rules of art. Genesis and structure of the literary field, Cambridge: Cambridge University Press.

British Army. (2017). Land Operations 3-01, Land Warfare Development Centre.

Broady, D. (1998). "Preface”, Kulturens fält, Gothenburg: Diadalos.

Cooper, J. (2018). The Russian State Armament Programme, 2018-2027, Russian studies, 01/18, Rome: NATO Defense College, 2018.

Deutsche Welle, (2016, March 18). "EU-Turkey migrant deal done”. Deutsche Welle. Retrieved from: https://www.dw.com/en/eu-turkey-migrant-deal-done/a-19127595.

European Commission, (2019 January 7). "1.5 million refugees in Turkey supported by EU's biggest ever humanitarian programme". European Commission. Retrieved from: http://europa.eu/rapid/ press-release_IP-19-1_en.htm.

Estonian Security Police, (2014). "Estonian Internal Security Service”, Estonian Internal Security Service: Annual Review 2013, Talinn: Estonian Security Police, p. 7.

Försvarsmakten. (2012). Militärstrategisk doktrin, Stockholm: Försvarsmakten.

Fridman, O. (2017). “Hybrid Warfare or Gibridnaya Voyna?", The RUSI Journal, 162(1), pp. 42-49.

Gibson, G (1999). “The Science in Science Fiction”, Talk of the Nation, NPR. Giles, K. (2016). Russia's 'New” Tools for Confronting the West Continuity \& Innovation in Moscow's Exercise of Power", London: Chatham House.

Greenfield, P. (2018). “Ukraine president proposes martial law after Russia seizes ships”, The Guardian, Europe Section.

Gunneriusson, H. (2017). Bordieuan Field Theory as an Instrument for Military Operational Analysis, Palgrave Macmillan, 2017, Chapter 11.

Gunneriusson H. \& S. Bachmann, S. (2017). “Western Denial \& Russian Control. How Russia’s National Security Strategy Threatens a Western-Based Approach to Global Security, the Rule of Law \& Globalization", Polish Political Science Yearbook, 46(1).

Gunneriusson H. \& Ottis, R. (2013). "Cyberspace from the Hybrid Threat Perspective”, The Journal of Information Warfare, 12(3).

Gunneriusson, H. (2012). "Nothing is taken seriously until it gets serious", Defence Against Terrorism review, IV(1), 2012, pp. 47-70.

Higgins, E. (2015). “Ukraine war: Brown Moses reveals apparent Russian attacks on Ukraine”. Youtube. Retrieved from: https://www.youtube.com/watch?v=s5bB1726gLg.

Hobbes, T. (1962) Leviathan. New York: Touchstone.

Hoffman, F. (2007). Conflict in the $21^{\text {st }}$ Century: The Rise of Hybrid Wars, Conflict in the $21^{\text {st }}$ Century: The Rise of Hybrid Wars. Arlington: Potomac Institute for Policy Studies. 
Interfax-Ukraine (2014). "Russian military plane shot down Ukrainian Su-25 aircraft in Ukraine”. Kyiv Post. Retrieved from: https://www.kyivpost.com/article/content/war-againstukraine/russian-militaryplane-shot-down-ukrainian-su-25-aircraft-in-ukraine-356422.html

Korybko, A. (2015). Hybrid Wars: The Indirect Adaptive Approach to Regime Change. Moscow: Peoples' Friendship University of Russia.

Kraska, J. (2018). “The Kerch Strait Incident: Law of the Sea or Law of Naval Warfare?”, EJIL: Talk!, https:// www.ejiltalk.org/the-kerch-strait-incident-law-of-the-sea-or-law-of-naval-warfare/.

Kyodo, (2018). “Duterte confident China will be 'fair' when resolving maritime disputes". South China Morning Post, South Seast Asia Section. Retrieved from: https://www.scmp.com/news/asia/southeastasia/article/2155709/duterte-confident-china-will-be-fair-when-resolving.

Marsh, C. (2017). “Developments in Russian Special Operations”. Ottawa: Canadian Forces Special Operations Forces Education \& Research Centre.

Mälksoo, M. (2018). "Countering hybrid warfare as ontological security management: the emerging practices of the EU \& NATO”, European Security, 27(3), pp. 375-378.

Mitzen, J. (2006). “Ontological security in world politics: state identity \& the security dilemma”, European journal of international relations, 12(3), p. 345.

Nordstream (2019). Nordstream. Retrieved from: https://www.nord-stream.com/press-info/pressreleases/a-record-volume-of-588-billion-cubic-metres-of-natural-gas-has-been-transported-throughthe-nord-stream-pipeline-in-2018-504/

Oliphant, R. (2017). "Russian warships fire cruise missiles at Isil targets near Palmyra”. The Telegraph. Retrieved from: https:/www.telegraph.co.uk/news/2017/05/31/russian-warships-fire-cruise-missilesisil-targets-near-palmyra/.

Oliphant, R. (2019). "Ukraine threatens Council of Europe boycott as Russia rejoins PACE five years after Crimea annexation ban”. The Telegraph. Retrieved from: https://www.telegraph.co.uk/ news/2019/06/25/pace-votes-allow-russia-return-five-years-ban-crimea-annexation/

Rettman, A. (2015). “EU breaks taboo on 'Russian forces in Ukraine”. EU Observer.

Retrieved from: https://euobserver.com/foreign/127667.

Seely, R. (2017). "Defining Contemporary Russian Warfare”, The RUSI Journal, 162(1). pp. 52-53.

Shiryaevskaya, A. \& Mazneva, E. (2018 July 8). "Russian Gas”, Bloomberg. Retrieved from: https://www. bloomberg.com/quicktake/russian-gas.

Snegovaya, M. (2015). "Reflexive control': Putin’s hybrid warfare in Ukraine is straight out of the Soviet playbook”, Business Insider.

Spearin, C. (2018). "NATO, Russia \& Private Military \& Security Companies", The RUSI Journal, 163(3), p. 68.

Tang, D. (2018). "China building 'military base' on disputed Bombay Reef in the Paracel Islands", The London Times.

The Associated Press, (2008). “Italy to pay Libya \$5 billion”. The Associated Press. Retrieved from: https:// www.nytimes.com/2008/08/31/world/europe/31iht-italy.4.15774385.html.

Unian, (2019). “Россия проводит стрельбы вблизи Керченского пролива” (“Russia conducts firing near the Kerch Strait”). Unian. Retrieved from: https://www.unian.net/war/10451193-rossiya-provoditstrelby-vblizi-kerchenskogo-proliva-smi.html.

Veljovski, G. et al., (2017). "The danger of 'hybrid warfare' from a sophisticated adversary: the Russian 'hybridity' in the Ukrainian conflict", Defense \& Security Analysis, 33(4), p. 297.

Wirt, J.J. (2017). “Life in the 'Gray Zone': observations for contemporary strategists”, Defense \& Security Analysis, 33(2), pp. 108-109. 
Yaffa, J. (2018). “Putin's Shadow Army Suffers a Setback in Syria”, New Yorker.

Yeni Safak, (2019). “Turkey's vice president meets EU humanitarian official". Yenisafak. Retrieved from:

https://www.yenisafak.com/en/news/turkeys-vice-president-meets-eu-humanitarian-official-3471112.

\section{Author}

\section{Dr Håkan Gunneriusson}

Hakan.Gunneriusson@fhs.se; Hakan.Gunneriuson@miun.se,Associate Professor War Studies, Swedish Defence University, Militärvetenskapliga institutionen, Marktaktiska sektionen \& Departement of Political Science, Mid Sweden University, Contact details: Mittuniversitetet 83125 Östersund, Sweden; Skype: Gunneriusson_h 